\title{
Depth Wise Distribution of Boron in Some Soils of Red and Laterite Zone of West Bengal, India
}

\author{
Prashanta Barman $^{1 *}$, Arup Sen ${ }^{1}$, Amit Phonglosa ${ }^{2}$ and Kallol Bhattacharyya ${ }^{1}$ \\ ${ }^{1}$ Department of Agricultural Chemistry and Soil Science, Bidhan Chandra Krishi \\ Viswavidyalaya, Mohanpur, Nadia, West Bengal - 741252, India \\ ${ }^{2}$ Regional Research and Technology Transfer Sub-Station, Orissa University of Agriculture and \\ Technology, Umerkote-764073, Nabarangpur, Odisha, India \\ *Corresponding author
}

\begin{tabular}{|c|c|}
\hline & A B S T R A C T \\
\hline & $\begin{array}{l}\text { The present dissertation work was undertaken to study the depth wise distribution of boron } \\
\text { in some soils of red \& laterite zone of West Bengal. Soil samples were collected from five }\end{array}$ \\
\hline Keywords & $\begin{array}{l}\text { analyzed to study the status of B and its different fractions and the relationship between } \\
\text { different B fractions and their relationship with soil properties. The available B recoveries }\end{array}$ \\
\hline $\begin{array}{l}\text { Red and laterite } \\
\text { soil, Readily soluble }\end{array}$ & $\begin{array}{l}\text { from all the selected surface soils were in low to deficient ranges }\left(0.50 \pm 0.25 \mathrm{mg} \mathrm{kg}^{-1} \text { soil }\right) \\
\text { and total B recoveries ranged from } 30.90 \pm 23.53 \mathrm{mg} \mathrm{kg}^{-1} \text { soil. The recoveries of different B }\end{array}$ \\
\hline & fractions from the surface soils were observed within ranges of $0.22-0.31$ (readily soluble \\
\hline $\begin{array}{l}\text { Oxide bound B, } \\
\text { Organically bound }\end{array}$ & $\begin{array}{l}\text { B), } 0.45-0.56 \text { (specifically adsorbed B), } 0.38-0.88 \text { (oxide bound B), } 0.30-0.87 \text { (organically } \\
\text { bound B) and } 11.32-60.66 \text { (residual B) } \mathrm{mg} \mathrm{kg}^{-1} \text {. All the boron fractions decreased with }\end{array}$ \\
\hline & increasing depth of soil except residual B fraction which increased with soil depth. The \\
\hline Article Info & $\begin{array}{l}\text { recoveries of the hot water extractable } \mathrm{B} \text { was signiticantly correlated with the recoveries of } \\
\text { total } \mathrm{B} \text {, residual } \mathrm{B} \text {, oxide bound } \mathrm{B} \text { and readily soluble } \mathrm{B} \text {. Readily soluble B and }\end{array}$ \\
\hline Acc & $\begin{array}{l}\text { specifically adsorbed B were significantly and positively correlated with each other. The } \\
\text { available B was significantly and positively correlated soil } \mathrm{pH} \text {, clay, available } \mathrm{N}, \mathrm{P}, \mathrm{K}, \mathrm{Fe} \text {, }\end{array}$ \\
\hline Available Online: & $\mathrm{Mn}$ and amorphous $\mathrm{Fe}$ and $\mathrm{Al}$ oxides. It was observed that all the $\mathrm{B}$ fractions had \\
\hline 10 Dece & significant and positive correlation with clay content, available $\mathrm{N}$ and $\mathrm{P}$ and amorphous $\mathrm{Fe}$ \\
\hline & $\begin{array}{l}\text { of the soil. The results emanating from the study revealed that the soils were low in } \\
\text { available B content and only minute fraction of total B is available to plant. }\end{array}$ \\
\hline
\end{tabular}

\section{Introduction}

The element boron is an important micronutrient indispensible for normal growth and development of plant. This element has a relatively narrow range between its phytotoxic and deficient limit in the soil. Boron is absorbed from the soil by plants as borate, a negatively charged ion (anion). In mineral soils, release of boron is usually quite slow. Much of the available soil boron is held rather tightly by soil organic material. As organic matter decomposition occurs boron is released with a portion being absorbed by plants, leached below the root zone area (especially in high rainfall/acid soil areas) or tied up (unavailable) under alkaline soil conditions. 
Boron deficiency is now a widespread phenomenon and affects crop growth both in acid as well as calcarious soil. The extent of B deficiency was about $2 \%$ in the year 1980 (Katyal and Vlek, 1985) and now it has increased to $18.3 \%$ (Shukla et al., 2014) in India. Boron deficiency is becoming more pronounced in red and lateritic, acidic, coarse textured alluvial soils of India leading to $33 \%$ of grid samples to be deficient altogether (68\% of soil samples from West Bengal are deficient) (Singh, 2008). Availability of B is generally low in acid soils of high rainfall areas because of leaching of $\mathrm{B}$ and adsorption by aluminium (Al) and iron $(\mathrm{Fe})$ oxide minerals (Tsadilas and Kassioti, 2005). Highly leached acid soils of northern Bengal pose serious problem of boron deficiency (Saha and Halder, 1998).

The micronutrient Boron present in soil solution and in minerals, but only B in soil solution can be readily available for plants uptake, although this constitutes less than $3 \%$ of total soil B (Tsadilas et al., 1994).

Boron concentration in soil solution is controlled by the different pools of B in soil fractions and their equilibration with the soil solution (Keren and Bingham, 1985). The partition of the forms of an element has been made using methods originally developed for selective dissolution of trace metals and various techniques have been used for soil $\mathrm{B}$ by chemical fractionation schemes. In these procedures, different forms of B present in the soils were generally differentiated into: water soluble, specifically adsorbed, oxide bound, organically bound and residual associated with soil silicates (Hou et al., 1994; Xu et al., 2001; Datta et al., 2002).

In West Bengal, The red and laterite soils occur in the districts of Birbhum, Bankura, Purulia, Jhargram, Burdwan and West mednapur. The soils are generally acidic $(\mathrm{pH}$
5.0 to 6.5$)$, high in Iron and aluminium oxide, poor in calcium, organic matter, available phosphate and bases. Very little information is available about the different $\mathrm{B}$ fractions in these soil and available informations were confined to surface soils only. Roots of many crops (such as pulses and oilseeds) may go beyond the surface layer to derive part of their nutrient requirements from the subsurface layers. Therefore, the information about the depth wise distribution of available B content in the soils is desirable. Keeping this in view our present investigation was carried out to study the depth wise distribution of B in red and laterite soils of west Bengal, their inter relationship and relationship of different $B$ fractions with soil properties.

\section{Materials and Methods}

Soil samples were collected from 5 representative locations (Kusmasuli, Telkata, Jhargram, Barakadra, Ruisanda) of red and laterite zone of West Bengal, India, at three different depths: surface $(0-0.15 \mathrm{~m})$, midsurface $(0.15-0.30 \mathrm{~m})$, and subsurface $(0.30-0.45 \mathrm{~m})$ layers (at least 5 samples from each location). These soils were air-dried, thoroughly mixed and ground to pass through a 2-mm sieve. Several important physicochemical properties of these soil samples were determined by following the standard methods detailed hereafter.

\section{Fractionation of different Boron pools in soil}

\section{Readily soluble boron}

Five grams of soil in duplicate were weighed into $50 \mathrm{ml}$ polyethylene centrifuge tubes to which $10 \mathrm{ml}$ of $0.01 \mathrm{M} \mathrm{CaCl}_{2}$ were added and shaken for 16 hours (Hou et al., 1994). After centrifuging at $10,000 \mathrm{rpm}$ for $30 \mathrm{~min}$ the supernatant solution was filtered through Whatman no 42 filter paper. Boron was 
determined in clear extracts using Azomethine-H (Wolf, 1971).

\section{Specifically adsorbed B}

The residue from the above step was then extracted with $10 \mathrm{ml}$ of $0.05 \mathrm{M} \mathrm{KH}_{2} \mathrm{PO}_{4}$ by shaking for 1 hour (Hou et al., 1994). After centrifugation, B was measured in the clear supernatant as described in the previous step because $\mathrm{KH}_{2} \mathrm{PO}_{4}$ was also found not to interfere with the estimation of $\mathrm{B}$ with Azomethine-H (Wolf, 1971).

\section{Oxide bound B}

The residue from the previous step was extracted with $20 \mathrm{ml}$ of $0.175 \mathrm{M} \mathrm{NH}_{4}$-oxalate, pH 3.25 by shaking for 4 hours (Hou et al., 1994). Most of these extracts had a yellow to slight reddish colour. The yellow colour was mainly due to $\mathrm{Fe}$ and the reddish colour was due to slight dissolution of organic matter. The colours were eliminated by treating the extracts with $\mathrm{NaOH}$ and $\mathrm{HClO}_{4}$ (Datta et al., 2002). After that $B$ in the clear extracts was determined by the carmine method (Hatcher and Wilcox, 1950).

\section{Organically bound B}

The residue from the $\mathrm{NH}_{4}$-oxalate extraction was treated with $20 \mathrm{ml}$ of $0.5 \mathrm{M} \mathrm{NaOH}$ by shaking for 24 hours followed by filtration through Whatman no. 42. The extracts of all samples except sand soils, were dark in colour due to the dissolution of organic matter. Therefore, $14 \mathrm{ml}$ of aliquot was taken in a Teflon beaker to destroy the organic matter and the same procedure was followed as described in case of oxide bound fraction. Final volume was made up to $7 \mathrm{ml}$. After centrifuging the samples at $10,000 \mathrm{rpm}$ for 15 minutes, B in the supernatant was determined with carmine reagent (Hatcher and Wilcox, 1950).

\section{Residual B fraction}

The residue from the previous step was dried and ground. $1 \mathrm{~g}$ subsample was taken into a $50 \mathrm{ml}$ Teflon beaker and few drops of concentrated $\mathrm{H}_{2} \mathrm{SO}_{4}, 5 \mathrm{ml}$ of $\mathrm{HF}(40 \%)$, and $0.5 \mathrm{ml}$ of $\mathrm{HClO}_{4}(60 \%)$ were added (Lim and Jackson, 1982). The beaker was placed on a hot plate at $135 \pm 5^{\circ} \mathrm{C}$ and the volume reduced to about $3 \mathrm{ml}$. Then, $5 \mathrm{ml}$ of concentrated $\mathrm{H}_{2} \mathrm{SO}_{4}$ and $5 \mathrm{ml}$ of $\mathrm{HF}(40 \%)$ were added and heating continued. Further HF was added in increments of 2-5 $\mathrm{ml}$ until complete digestion of the soil. After digestion, 3 to $5 \mathrm{ml}$ of $\mathrm{HClO}_{4}(60 \%)$ was added depending upon the intensity of colour in the extract to get a clear extract. Finally, the volume was reduced to 3 to $4 \mathrm{ml}$ by heating to drive off $\mathrm{HF}$ and $\mathrm{HClO}_{4}$ completely. The content was transferred to a polyethylene centrifuge tube and the volume was made up to $25 \mathrm{ml}$. After centrifuging at $10,000 \mathrm{rpm} \mathrm{B}$ in the clear supernatant was determined with carmine reagent (Hatcher and Wilcox, 1950).

\section{Results and Discussion}

\section{Physico-chemical properties of the collected soil}

The soils have been characterized by determining important physico-chemical properties and the observations have been recorded in table 1 . The soils are mildly acidic $(\mathrm{pH}-5.83 \pm 0.14)$ and medium to low in organic carbon $\left(5.24 \pm 1.86 \mathrm{~g} \mathrm{~kg}^{-1}\right.$ surface soil) content. The clay content, which in surface soil varies from $185.4 \pm 157.74$, highest in Ruisanda soil and lowest in Jhargram soil. The available $\mathrm{N}\left(209.32 \pm 32.05 \mathrm{mg} \mathrm{kg}^{-1}\right)$, available $\mathrm{P}\left(25.36 \pm 5.86 \mathrm{mg} \mathrm{kg}^{-1}\right)$ and available $\mathrm{K}\left(131.62 \pm 49.52 \mathrm{mg} \mathrm{kg}^{-1}\right)$ are low in the collected soils. As for the micronutrients, DTPA extractable $\mathrm{Zn}$ and $\mathrm{Cu}$ are low to deficient $(1.11 \pm 0.171$ and $1.06 \pm 0.16$ respectively) and Available (DTPA) Fe and 
$\mathrm{Mn}$ in the red and laterite soil are exorbitantly high $\left(50.99 \pm 10.38\right.$ and $47.72 \pm 11.29 \mathrm{mg} \mathrm{kg}^{-1}$, respectively).

These soils were further analyzed to determine the depth wise profile of important physico-chemical characteristics (Table 1). The $\mathrm{pH}$ of the selected soils has been found to increase with increasing depth of sampling (up to $45 \mathrm{~cm}$ ). This is because the upper horizons receive maximum leaching by rainfall, and by dissolved carbonic acid and organic acids which remove metal cations (e.g., $\mathrm{Ca}^{2+}, \mathrm{K}^{+}, \mathrm{Mg}^{2+}$ ) and replace them with $\mathrm{H}^{+}$ions. Lower horizons are not so strongly leached and, in fact, in dryer areas may accumulate calcium and other materials removed from the upper soil (Brady and weil, 2008). Other soil parameters showed gradual decline with increasing depth of sampling as also substantiated by Jobbagy and Jackson (2001) who found topsoil concentrations of all nutrients were higher than in the lower soil profiles where the elements were scarcer.

\section{B fractions and their relation with soil properties}

The recoveries of different fractions of $\mathrm{B}$ from soils, their extent, proportions to account for the total B pool and availability to standing crop largely depends upon the soil properties. Total B recoveries however, is not considered as a reliable index to understand the B supplying capacity of the respective soils. The plant available pools are often dictated by different B pools and soil physicochemical properties. The B recoveries from selected soils of these zones have been recorded in table 2 .

\section{Hot water soluble B (HWSB)}

The average HWSB recoveries from the selected surface soils ranged from 0.14-0.71 $\mathrm{mg} \mathrm{kg} \mathrm{kg}^{-1}(0.50 \pm 0.25)$ in (Table 1) which accounted for $1.61 \%$ of total $\mathrm{B}$ recoveries.
This findings can be well substantiated by Raza et al., (2002) reporting an average of $1 \%$ of the total soil B as HWSB, which is considered most available for plant uptake.

The available B (HWSB) recoveries were found to decrease (Table 2) with increasing depth of sampling to $15-30$ and $30-45 \mathrm{~cm}$ $\left(0.43 \pm 0.20\right.$ to $\left.0.35 \pm 0.17 \mathrm{mgkg}^{-1}\right)$. This is due to leaching which was more pronounced in relatively light textured red and lateritic soils.

Similar trends of depth wise profile B recoveries have been reported by Arora and chahal (2005), Chaudhary and Shukla (2003).

The recoveries of the HWSB (plant available B) was observed to be significantly correlated with the recoveries of total $\mathrm{B}$, residual $\mathrm{B}$ and oxide bound B (Table 3). Ho and Houng (1991) found an important correlation between hot water extractable B and total soil $\mathrm{B}$ together with fixation of supplemental B.

Datta et al., (2002) has identified that 75\% variability in the hot $\mathrm{CaCl}_{2}$ extractable $\mathrm{B}$ (Hcc-B) could be attributed to RsB, SpB, $\mathrm{OxB}$, and $\mathrm{OrgB}$. Similar relationships have also been observed by Anitha et al., (2013) who reported that the available boron content has significant and positive correlations with readily soluble, specifically adsorbed and oxide bound boron.

The hot water soluble B (HSWB) is significantly and positively correlated with soil $\mathrm{pH}$, clay content, available N, P, K (Table 4). Sarkar et al., (2008) also found significant and positive correlation with soil $\mathrm{pH}$. As the soil is highly weathered soil, rich in iron and aluminium oxide, large portion of B is bound with these oxides. Thus we got a significant positive correlation of HWSB with available $\mathrm{Fe}, \mathrm{Mn}$ and amorphous $\mathrm{Fe}$ and $\mathrm{Al}$ (Table 4). A positive correlation $\left(\mathrm{r}=0.584^{*}\right)$ was also found with oxide bound B and HWSB. 
The Readily Soluble B (Rs_B) and the specifically adsorbed B (Sp_B)

Readily soluble B includes dissolved plus B adsorbed nonspecifically on edges of clays and other variable charge surfaces. This fraction varied from 0.22 to $0.31 \mathrm{mgkg}^{-1}$ $(0.27 \pm 0.04)$ in surface soil and contribute $0.87 \%$ of total B (Table 2). The recovery of specifically adsorbed B varied from 0.45 to $0.56 \mathrm{mgkg}^{-1}(0.49 \pm 0.08)$ in top layer, which share almost $1.58 \%$ of total B (Table 2). Both the fractions significantly and positively correlated $\left(\mathrm{r}=0.693^{* *}\right)$ with each other means there is a dynamic equilibrium between these two fractions. Kusum Kumari et al., (2017) also found significant positive relation $\left(\mathrm{r}=0.980^{* *}\right)$ between readily soluble $\mathrm{B}$ and specifically adsorbed B. Both readily soluble $\mathrm{B}$ and specifically adsorbed B have significant and positive correlation with available $\mathrm{N}\left(\mathrm{r}=0.584^{*}\right.$ and $\left.0.652^{* *}\right), \quad \mathrm{P}$ $\left(\mathrm{r}=0.672^{* *}\right.$ and $\left.696^{* *}\right)$ and amorphous $\mathrm{Fe}$ $\left(\mathrm{r}=0.618^{*}\right.$ and $\left.0.726^{* *}\right), \mathrm{Al}\left(\mathrm{r}=0.561^{*}\right.$ and
0.719**). We found significant positive correlation between specifically adsorbed B and clay content $(\mathrm{r}=0.580 *)$. The clay content, which affected on B sorption process, could have a dominating effect on specifically adsorbed $\mathrm{B}$ fraction, as also observed by $\mathrm{Xu}$ et al., (2001). Although, Hou et al., (1994) and Datta et al., (2002) failed to establish any significant correlations of specifically adsorbed B with clay or with $\mathrm{NH}_{4}$-oxalate extractable $\mathrm{Al}$ and $\mathrm{Fe}$. This fraction probably originates from the weakly binding sites of both organic and inorganic constituents and none of these constituents contributed exclusively towards this B fraction (Hou et al., 1994).

Both the fractions decreased with increasing depth of soil (Table 2 and Figure 1). This decrease may be due to decreasing organic carbon content, clay content and Fe content with depth (Table 1). Sarkar et al., (2008) also observed similar type findings.

Important physico-chemical properties of these soil samples

\begin{tabular}{|c|c|c|}
\hline Soil Parameters & Methodologies & References \\
\hline $\mathrm{pH}$ & Soil-water suspension $(1: 2.5)$ & Jackson, 1973 \\
\hline $\mathrm{EC}$ & Soil-water suspension $(1: 2.5)$ & Jackson, 1973 \\
\hline Clay content & Hydrometer method & Bouyoucos, 1962 \\
\hline Organic Carbon & Wet digestion method & Walkley and Black, 1934 \\
\hline $\begin{array}{l}\text { Amorphous } \mathrm{Fe}, \mathrm{Al} \text { and } \mathrm{Mn} \\
\text { oxides }\end{array}$ & 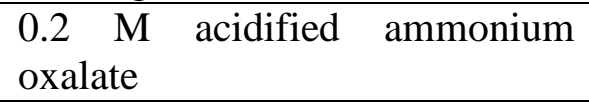 & McKeague and Day, 1966 \\
\hline Available N & Hot alkaline permanganate & Subbiah and Asija, 1956 \\
\hline Available $\mathrm{P}$ & $0.5 \mathrm{M} \mathrm{NaHCO}_{3}$ & Olsen et al., 1954 \\
\hline Available P & $\begin{array}{l}0.03 \mathrm{~N} \mathrm{NH}_{4} \mathrm{~F}+0.025 \mathrm{~N} \mathrm{HCL} \\
(\mathrm{pH} 3.5)\end{array}$ & Bray and Kurtz, 1945 \\
\hline Available K & $\begin{array}{l}\text { Neutral Normal ammonium } \\
\text { acetate extraction }\end{array}$ & Brown \& Warncke, 1988 \\
\hline $\begin{array}{l}\text { Available } \\
\mathrm{Cu}^{2+}, \mathrm{Fe}^{2+}\end{array} \quad \mathrm{Zn}^{2+}, \quad \mathrm{Mn}^{2+}$, & DTPA extractant & Lindsay\& Norvel, 1978 \\
\hline Available $\mathrm{B}\left(\mathrm{mg} \mathrm{kg}^{-1}\right)$ & Hot water extraction & Berger and Truog, 1939 \\
\hline Total boron $\left(\mathrm{mg} \mathrm{kg}^{-1}\right)$ & Aqua Regia + HF dissolution & $\begin{array}{l}\text { Zarcinas and Cartwright, } \\
1987\end{array}$ \\
\hline
\end{tabular}


Table.1 Depth wise physio-chemical properties of the collected soils

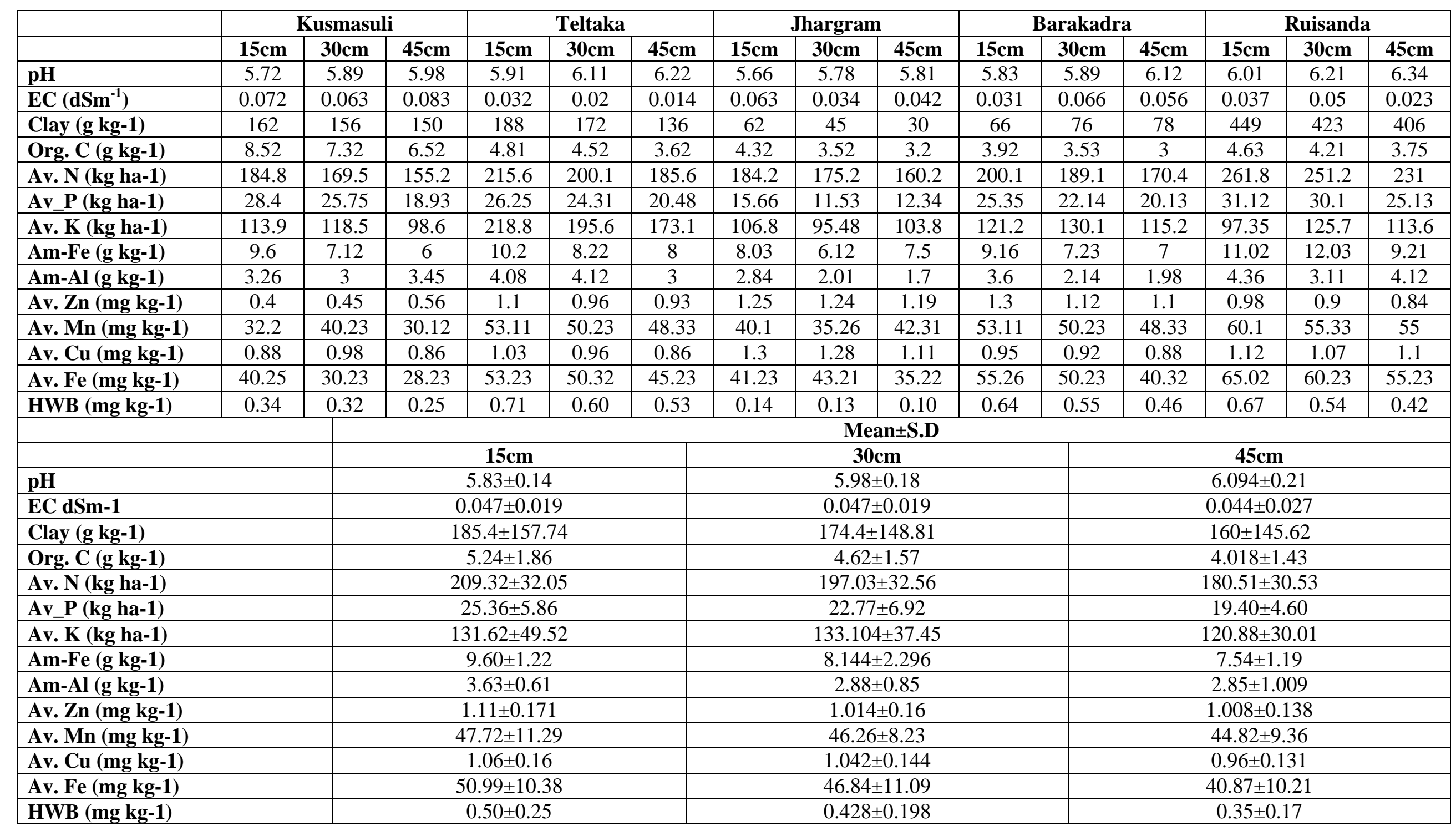


Table.2 Depth wise distribution of B in red and lateritic soils

\begin{tabular}{|c|c|c|c|c|c|c|c|c|c|c|c|c|c|c|c|}
\hline & \multicolumn{3}{|c|}{ Kusmasuli } & \multicolumn{3}{|c|}{ Teltaka } & \multicolumn{3}{|c|}{ Jhargram } & \multicolumn{3}{|c|}{ Barakadra } & \multicolumn{3}{|c|}{ Ruisanda } \\
\hline & $15 \mathrm{~cm}$ & $30 \mathrm{~cm}$ & $45 \mathrm{~cm}$ & $15 \mathrm{~cm}$ & $30 \mathrm{~cm}$ & $45 \mathrm{~cm}$ & $15 \mathrm{~cm}$ & $30 \mathrm{~cm}$ & $45 \mathrm{~cm}$ & $15 \mathrm{~cm}$ & $30 \mathrm{~cm}$ & $45 \mathrm{~cm}$ & $15 \mathrm{~cm}$ & $30 \mathrm{~cm}$ & $45 \mathrm{~cm}$ \\
\hline Rs_B & 0.25 & 0.24 & 0.20 & 0.30 & 0.22 & 0.24 & 0.22 & 0.21 & 0.15 & 0.29 & 0.25 & 0.16 & 0.31 & 0.26 & 0.18 \\
\hline Sp_B & 0.46 & 0.44 & 0.39 & 0.59 & 0.46 & 0.25 & 0.40 & 0.35 & 0.28 & 0.45 & 0.28 & 0.30 & 0.56 & 0.54 & 0.38 \\
\hline Ox_B & 0.38 & 0.35 & 0.29 & 0.52 & 0.48 & 0.41 & 0.43 & 0.35 & 0.42 & 0.5 & 0.56 & 0.54 & 0.88 & 0.74 & 0.77 \\
\hline Org_B & 0.87 & 0.85 & 0.8 & 0.4 & 0.45 & 0.39 & 0.44 & 0.38 & 0.34 & 0.3 & 0.25 & 0.18 & 0.65 & 0.6 & 0.51 \\
\hline Res_B & 11.32 & 12.23 & 14.23 & 42.32 & 42.34 & 44.23 & 14.23 & 15.13 & 16 & 9.36 & 11.12 & 12.01 & 60.66 & 62.2 & 65.62 \\
\hline Unac_B & 0.4 & 1.08 & 2.48 & 1.62 & 4.26 & 5.08 & 1.67 & 0.79 & 0.72 & 2.25 & 1.6 & 2.05 & 2.43 & 1.87 & 0.55 \\
\hline \multirow[t]{3}{*}{ Tot_B } & 13.56 & 15.2 & 18.5 & 45.5 & 48.21 & 50.97 & 17.2 & 17.22 & 18.1 & 12.85 & 13.99 & 15.45 & 65.37 & 66.21 & 68.32 \\
\hline & \multicolumn{7}{|c|}{ Mean \pm S.D } & \multicolumn{8}{|c|}{ \% contribution to total (mean value) } \\
\hline & \multicolumn{2}{|c|}{$15 \mathrm{~cm}$} & \multicolumn{3}{|c|}{$30 \mathrm{~cm}$} & \multicolumn{2}{|c|}{$45 \mathrm{~cm}$} & \multicolumn{3}{|c|}{$15 \mathrm{~cm}$} & \multicolumn{2}{|c|}{$30 \mathrm{~cm}$} & \multicolumn{3}{|c|}{$45 \mathrm{~cm}$} \\
\hline Rs_B & \multicolumn{2}{|c|}{$0.27 \pm 0.04$} & \multirow{2}{*}{\multicolumn{3}{|c|}{$\frac{0.24 \pm 0.02}{0.41 \pm 0.10}$}} & \multicolumn{2}{|c|}{$0.19 \pm 0.04$} & \multicolumn{3}{|c|}{0.87} & \multicolumn{2}{|c|}{0.74} & \multicolumn{3}{|c|}{0.55} \\
\hline Sp_B & \multicolumn{2}{|c|}{$0.49 \pm 0.08$} & & & & \multicolumn{2}{|c|}{$0.32 \pm 0.06$} & \multicolumn{3}{|c|}{1.58} & \multicolumn{2}{|c|}{1.27} & \multicolumn{3}{|c|}{0.93} \\
\hline Ox_B & \multicolumn{2}{|c|}{$0.54 \pm 0.20$} & & \multicolumn{2}{|c|}{$\begin{array}{c}0.41 \pm 0.10 \\
0.50 \pm 0.16\end{array}$} & \multicolumn{2}{|c|}{$0.49 \pm 0.18$} & \multicolumn{3}{|c|}{1.74} & \multicolumn{2}{|c|}{1.55} & \multicolumn{3}{|c|}{1.42} \\
\hline Org_B & & \pm 0.23 & & \multicolumn{2}{|c|}{$0.51 \pm 0.23$} & $0.44 \pm$ & & & 1.71 & & & & & 1.28 & \\
\hline Res_B & 27.5 & \pm 22.84 & & $28.60 \pm 22$. & & $30.42 \pm$ & 3.66 & & 89.25 & & & & & 88.7 & \\
\hline Unac_B & & \pm 0.77 & & $1.91 \pm 1.3$ & & $2.41 \pm$ & & & 4.79 & & & & & 7.03 & \\
\hline Tot_B & 30.9 & \pm 23.53 & & $32.17 \pm 23$. & & $34.27 \pm$ & 3.99 & & & & & & & & \\
\hline
\end{tabular}

Table.3 Relationship between different B pools in selected soil

\begin{tabular}{|l|r|r|r|r|r|r|r|}
\hline \multicolumn{7}{|c|}{ Correlations } \\
\hline & HWSB & \multicolumn{1}{|c|}{ Rs_B } & Sp_B & Ox_B & Org_B & Res_B & Tot_B \\
\hline HWSB & 1 & & & & & & \\
\hline Rs_B & $0.655^{*}$ & 1 & & & & & \\
\hline Sp_B & 0.486 & $0.693 * *$ & 1 & & & & \\
\hline Ox_B & $0.584 *$ & 0.312 & 0.392 & 1 & & & \\
\hline Org_B & -0.123 & 0.208 & 0.448 & -0.116 & & & \\
\hline Res_B & $0.563 *$ & 0.258 & 0.425 & $0.761 * *$ & .098 & & \\
\hline Tot_B & $0.580^{*}$ & 0.265 & 0.415 & $0.746^{* *}$ & .095 & $0.998^{* *}$ & \\
\hline
\end{tabular}

* Correlation is significant at the 0.05 level (2-tailed). **. Correlation is significant at the 0.01 level (2-tailed). 
Table.4 Relationship between B fractions and soil properties

\begin{tabular}{|c|c|c|c|c|c|c|c|c|c|c|c|c|c|}
\hline & $\mathrm{pH}$ & $\mathrm{EC}$ & Clay & Org. C & Av. N & Av. P & Av. K & $\mathrm{Am}-\mathrm{Fe}$ & $\mathrm{Am}-\mathrm{Al}$ & Av. Zn & Av. Mn & Av. $\mathrm{Cu}$ & Av. Fe \\
\hline HWSB & $0.502^{*}$ & -0.416 & $0.504 *$ & -0.094 & $0.669 * *$ & $0.767 * *$ & 0.630 * & $0.614^{*}$ & $0.622 *$ & 0.030 & $0.777 * *$ & -0.403 & $0.721 * *$ \\
\hline Rs_B & -0.134 & -0.123 & 0.345 & 0.255 & $0.584 *$ & $0.672 * *$ & 0.326 & $0.618^{*}$ & $0.561 *$ & -0.010 & 0.409 & -0.050 & $0.586^{*}$ \\
\hline Sp_B & -0.042 & -0.027 & $0.580^{*}$ & 0.400 & $0.652 * *$ & $0.696^{* *}$ & 0.247 & $0.726^{* *}$ & $0.719 * *$ & -0.179 & 0.316 & 0.175 & 0.486 \\
\hline Ox_B & $0.530 *$ & -0.333 & $0.809 * *$ & -0.353 & $0.903 * *$ & $0.591 *$ & -0.029 & $0.726 * *$ & 0.427 & 0.190 & $0.852 * *$ & 0.196 & $0.853 * *$ \\
\hline Org_B & -0.076 & 0.438 & 0.414 & $0.893 * *$ & 0.073 & 0.425 & -0.228 & 0.178 & 0.406 & $-0.879 * *$ & -0.397 & -0.121 & -0.253 \\
\hline Res_B & $0.739 * *$ & $-0.574^{*}$ & $0.875^{* *}$ & -0.214 & $0.839 * *$ & $0.520 *$ & 0.310 & $0.691 * *$ & $0.618 *$ & -0.036 & $0.690 * *$ & 0.159 & $0.709 * *$ \\
\hline Tot_B & $0.752 * *$ & $-0.583 *$ & $0.865 * *$ & -0.215 & $0.829 * *$ & $0.522 *$ & 0.330 & $0.680 * *$ & $0.626^{*}$ & -0.039 & $0.691 * *$ & 0.130 & $0.703 * *$ \\
\hline
\end{tabular}

**. Correlation is significant at the 0.01 level (2-tailed).

*. Correlation is significant at the 0.05 level (2-tailed).

Fig.1 Depth wise distribution of different B fractions
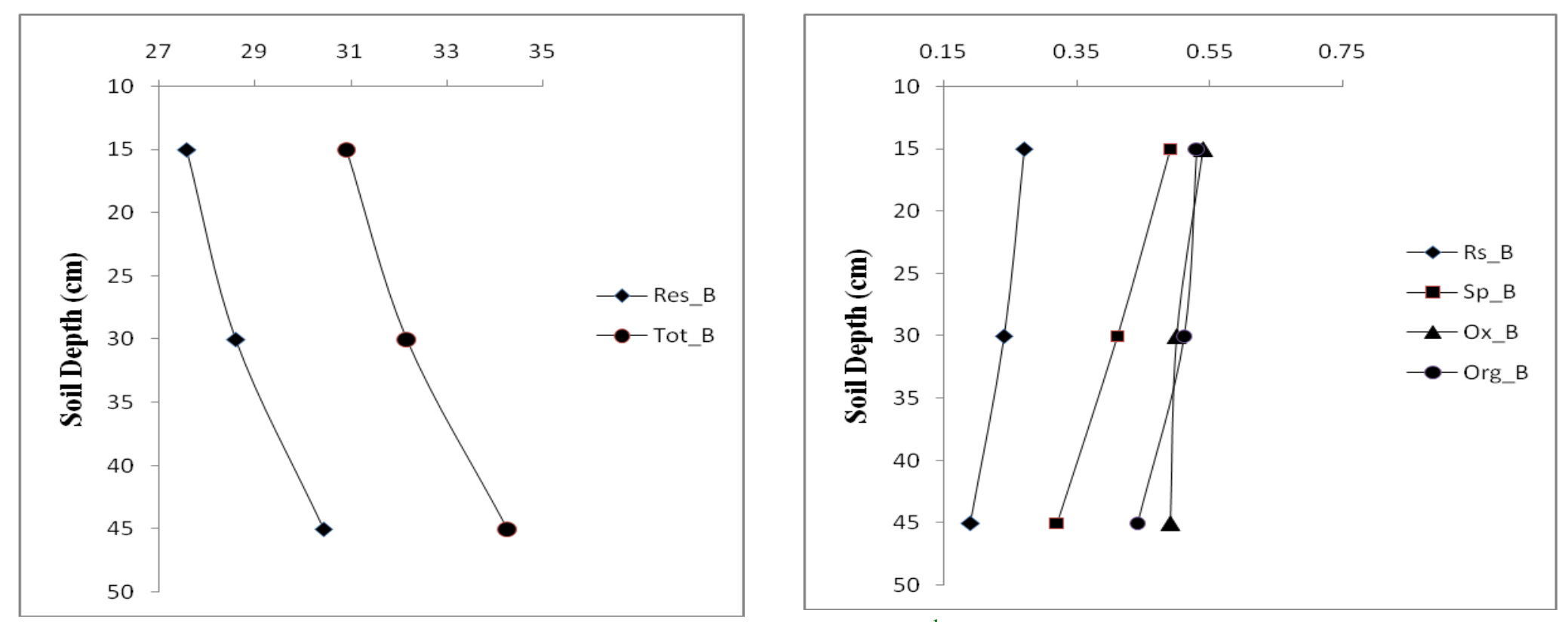

Boron concentration $\left(\mathrm{mg} \mathrm{kg}^{-1}\right)$ 


\section{The oxide bound $\mathrm{B}\left(\mathrm{Ox} \_\mathrm{B}\right)$}

The oxide bound $\mathrm{B}$ fraction included tightly bound B at mineral surfaces as well as B that has isomorphously replaced $\mathrm{Al}$ or $\mathrm{Fe}$ within the octahedral sheet of the minerals (Hou 1994). The recoveries of the oxide bound $B$ (Ox_B) from the selected surface soils were ranged from 0.38 to $0.88 \mathrm{mg} \mathrm{kg}^{-1}$ (Table 2). This fraction has significant positive correlation with Hot water soluble B and residual B fraction (Table 3). So this fraction has a contribution to plant available form of B. Kusum Kumari et al., (2017) also observed significant and positive correlation among these fractions. The oxide bound $\mathrm{B}$ also significantly and positively correlated with $\mathrm{pH}$, clay, available $\mathrm{N}, \mathrm{P}, \mathrm{Mn}, \mathrm{Fe}$ and amorphous $\mathrm{Fe}$ and $\mathrm{Al}$ oxides.

Datta et al., (2002) observed that $\mathrm{pH}$ and $\mathrm{NH}_{4}$-oxalate extractable $\mathrm{Fe}$ are the main contributors of oxide bound B explaining $42 \%$ variability of this fraction. As $\mathrm{NH}_{4-}$ oxalate can solubilize non-crystalline and some crystalline oxy-hydroxides of $\mathrm{Fe}$ and $\mathrm{Al}$ from soils, the relationship of oxide bound $\mathrm{B}$ and $\mathrm{NH}_{4}$ - oxalate extractable $\mathrm{Fe}$ is logical as an adsorption of $\mathrm{B}$ both as $\mathrm{B}(\mathrm{H})_{3}{ }^{0}$ and $\mathrm{B}(\mathrm{OH})_{4}$ species takes place on $\mathrm{Fe}_{2} \mathrm{O}_{3}$ via ligand exchange (Su and Suarez, 1995). Our findings are also in good agreement with observations of Colak et al., (2013) who reported that B occluded in Mn oxides and occluded in amorphous $\mathrm{Fe}-\mathrm{Al}$ oxyhydroxides were correlated with soil properties such as: organic matter content, $\mathrm{pH}$, free aluminum and iron oxyhydroxides, amorphous aluminum and iron oxy-hydroxides. This fraction was also decreased with depth soil (Table 2 and Figure 1) mainly due to the decrease in clay content and amorphous $\mathrm{Fe}$ and $\mathrm{Al}$ oxide content of the soils at lower depths, as evidenced by significant positive correlations between the extractable $\mathrm{B}$ with those soil properties.

\section{The organically bound B (Org_B)}

The recoveries of organically bound B from selected soils ranged from 0.30 to $0.87 \mathrm{mg}$ $\mathrm{kg}^{-1}$ (Table 2). This fraction under the present study were observed to be significantly and positively correlated with organic $\mathrm{C}$ content $\left(0.893^{* *}\right)$. Such observations are complimented by similar findings of Datta et al., (2002) who observed that organically bound B was positively correlated with organic carbon content.

The significant relationship observed between organically bound B fraction and OM content indicated that organic matter played an important role in B adsorption and release in soils (Ranjbar and Jalali, 2013). This fraction solely depended on the organic carbon content of the soil (Kartikeyan and Sukla, 2011). The close association of soil organic matter with organically bound B may be attributed to the release of $\mathrm{B}$ when organic matter decomposition occurs in soil (Jin et al., 1987).

As organic carbon content decreased with soil depth this fraction also decreased with increasing soil depth (Figure 1).

\section{The residual B (Res_B)}

Boron held within primary (tourmaline) and secondary (colemanite) minerals is described as residual B (Res_B). Residual B is generally associated with silicates (Jin et al., 1987). Residual B accounts for the major portion of total soil B. The recoveries of residual B from selected surface soils under the present investigation were observed to be 11.32 to $60.66 \mathrm{mg} \mathrm{kg}^{-1}$ (Table 1). The greatest significant correlation was observed between residual $\mathrm{B}$ and total $\mathrm{B}\left(\mathrm{r}=0.99^{* *}\right)$ followed by relationship between residual $\mathrm{B}$ and oxide bound $\mathrm{B}\left(\mathrm{r}=0.76^{* *}\right)$ (Table 3$)$. The greatest correlation between residual $\mathrm{B}$ and total $\mathrm{B}$ 
might be due to among all the extracted fractions as it contributed to the tune of 89.25 $\%$ to total B fraction (Table 2). This residual $\mathrm{B}$ significantly and positively correlated with $\mathrm{pH}$, clay, available $\mathrm{N}, \mathrm{P}$, amorphous $\mathrm{Fe}, \mathrm{Al}$ oxides and available $\mathrm{Fe}, \mathrm{Mn}$ (Table 4). Similar findings have also been reported by Datta et al., (2002) who observed that residual $\mathrm{B}$ was significantly and positively correlated with clay, $\mathrm{Al}, \mathrm{Fe}$, and $\mathrm{Al}+\mathrm{Fe}$ which confirms that the residual $\mathrm{B}$ is the structural constituent of clay and sesquioxides. The residual $\mathrm{B}$ also includes B occluded in crystalline $\mathrm{Al}$ and $\mathrm{Fe}$ oxyhydroxides (Xu et al., 2001). The residual $\mathrm{B}$ has been observed to increase with depth from $15 \mathrm{~cm}$ to $45 \mathrm{~cm}$ which actually accounted for the increase in total B recoveries with increasing depth of sampling (Figure 1). The structural B (clay lattice and alumino-silicates bound residual B) were higher at depth of the soil profile where the soils are less disturbed and beyond plough reach.

The proportionate recoveries of different fractions of $\mathrm{B}$ with respect to total boron recoveries have been presented in Table 2 . We found that the contents of $\mathrm{B}$ fractions followed the order Residual $\mathrm{B} \gg$ Oxide bound $\mathrm{B} \cong$ Organically bound $\mathrm{B}>$ specifically adsorbed B > Readily soluble B. Our finding matches with the observation of Diana and Beni (2006) who said that the contents of B fractions followed the order Res-B $>$ Ox-B > Om-B > Sol-B $>$ Spa-B $\cong$ Nsa-B.

The present investigation has made a modest attempt to characterize boron in some soils randomly selected from these agriculturally most important regions of the state. We have sorted to the $\mathrm{B}$ fractionation scheme developed by Hou et al., (1994) and later modified by Datta et al., (2002) for colorimetric determination instead of costly ICP-OES studies. The B fractions recovered from different soils, their interrelationship and relationship with soil properties have been worked out throughout the present initiative. A thorough investigation regarding B status, availability and soil factors controlling such availability have been explored. The database generated through the present investigation may help extending our understanding of the $\mathrm{B}$ behavior and $\mathrm{B}$ availability in a wide range of cultivable lands in the state and to ignore artifacts relating to $\mathrm{B}$ availability/or deficiencies.

\section{References}

Anitha, M.S., Anil kumar, K.S., Nair, K.M., Shivaprasad, C.R., Naidu, L.G.K., and Sarkar, D. 2013. Soil Boron and Its Fractions in Agro-Climatic Zones of Karnataka. Clay Research. 32 (1),25-33.

Arora, S., and Chahal, D. S. 2005. Available boron content in some benchmark soils of Punjab under different moisture regimes in relation to soil characteristics. Agropedology. 15 (2), 90-94.

Berger, K. C., and Truog, E. 1939. Boron determination in soils and plants. Industrial and Engineering Chemistry, Analytical Edition. 11, 540- 545.

Bouyoucos, G. J. 1962. Hydrometer method improved for making particle size analysis of soils. Agronomy Journal. 54, 464-465.

Brady, N. C., and Weil, R.C. 2008. The nature and properties of soil. Revised fourteenth edition, Pearson education publishers.

Bray, R.H., and Kurtz, L.T. 1945. Determinations of total, organic and available forms of phosphorus in soils. Soil Science. 59, 39-45.

Brown, A. J., and Warncke, D. 1988. In W. C. Dahnke (Ed.) Recommended chemical soil test procedures for the North Carolina Region. North Dakota Agricultural Experimental Station Bull. 
499, 15-16.

Chaudhary, D.R., and Shukla, L.M. 2003. Profile distribution of boron forms in relation to soil characteristics in arid soils of western Rajasthan. Annals of Agricultural Research. 24, 314-321.

Colak, B., Korkmaz, A., and Horuz, A. 2013. Boron status, boron fractions and its availability in sugar beet grown soils. Anadolu Journal of Agricultural Sciences. 28 (3), 157-167.

Datta, S. P., Rattan, R. K., Kandregula, S., and Datta, S. C. 2002. Fractionation and colorimetric determination of boron in soils. Journal of Plant Nutrition and Soil Science. 165, 179-184.

Diana, G., and Beni, C. 2006. Effect of organic and mineral fertilization on soil boron fractions. Agr. Med. 13, 70-78.

Gupta, U.C. 1979. Boron nutrition of crops. Advances in Agronomy. 31, 273- 307.

Hatcher, J.T., and Wilcox, L.V. 1950. Colorimetric determination of boron using carmine. Analytical Chemistry. 22, 567- 569.

Ho, S. B., and Houng, K. H. 1991. Studies on the hot water soluble boron in Taiwan agricultural soils. I. The examination of the method. Journal of Chinese Agricultural Chemistry Society. 29(2): 135-144.

Hou, J., Evans, L.J., and Spiers, G.A. 1994. Boron fractionation in soils. Communications in Soil Science and Plant Analysis. 25 (9-10): 1841-1853.

Jackson, M.L., 1973. Soil Chemical Analysis. Prentice Hall of India Pvt. Ltd., New Delhi, India.

Jin, J., Martens, D.C., and Zelazny, L.W. 1987. Distribution and plant availability of soil boron fractions. Soil Science Society of America Journal. 51, 12281231.

Jobbágy, E. G., and Jackson, R. B. 2001. The distribution of soil nutrients with depth: Global patterns and the imprint of plants. Biogeochemistry. 53, 51-77.

Karthikeyan, K., and Shukla, L. M. 2011. Different forms of boron and sulphur and their effect on B and S contents in mustard (Brassica juncea L.) and sunflower (Helianthus annus L.). Agropedology. 21(1): 28-34.

Katyal, J.C., and Vlek, P.L.G. 1985. Micronutrient problem in tropical Asia. Fertil. Res. 7: 69-94.

Keren, R., Bingham, F.T., and Rhoades, J.D. 1985. Plant uptake of boron as affected by boron distribution between liquid and solid phases in soil. Soil Science Society of America Journal. 49, 297302.

Kumari, K., Nazir, G., Singh, A., and Kumar, P. 2017. Studies on Boron Fractions with Different Physico-Chemical Properties of Cultivated Soils of Himachal Pradesh, India Int.J.Curr. Microbiol.App.Sci. 6(6): 1547-1555.

Lim, C. H., and Jackson, M. L. 1982. Dissolution for total elemental analysis. In A. L. Page et al., (eds.): Methods of Soil Analysis. Agronomy 9, Am. Soc. Agron., Soil Sci. Soc. Am., Inc., Madison, Wis., p. 1-11.

Lindsay, W.L., and Norvell, W.A. 1978. Development of DTPA soil test for Zn, $\mathrm{Fe}, \mathrm{Mn}$ and $\mathrm{Cu}$. Soil Science Society of the America Journal. 42, 421-428.

McKeague, J.A., and Day, J.H. 1966. Dithionite- and oxalate- extractable Fe and $\mathrm{Al}$ as aids in differentiating various classes of soils. Canadian Journal of Soil Science. 46, 13-22.

Olsen, S.R., Cole, C.V., Watanale, F.S., and Dean, L.A. 1954. Estimation of available phosphorus in phosphorus in soils by extraction with sodium bicarbonate. Circular 393, United States Department of Agriculture, Washington DC.

Ranjbar, F., and Jalali, M. 2013. Release kinetics and distribution of boron in 
different fractions in some calcareous soils. Environmental Earth Sciences. 70 (3):1169-1177.

Raza, M., Mermut, A. R., Schoenau, J. J., and Malhi, S. S. 2002. Boron fractionation in some Saskatchewan soils. Canadian Journal of Soil Science. 82, 173-179.

Saha, A. R., and Haldar, M. 1998. Effect of phosphorus, lime and boron application on the changes in available Band $\mathrm{P}$ content of Aeric Haplaquept. Journal of the Indian Society of Soil Science. 46, 22-26.

Sarkar, D., Mandal. B, Kundu, M.C., and Bhat, J.A. 2008. Soil Properties Influence Distribution of Extractable Boron in Soil Profile. Communications in Soil Science and Plant Analysis. 39:15-16, 2319-2332.

Shukla, A.K., Tiwari, P.K., and Prakash, C. 2014. Micronutrients deficiencies vis-a vis food and nutritional security of India. Indian J. Fert. 10, 94-112.

Singh, M.V. 2008. Micronutrient Deficiencies in Crops and Soils in India. In: Brian J. Alloway ed. Micronutrient Deficiencies in Global Crop Production. pp 93-125.

Su, C., and Suarez, D. L. 1995. Coordination of adsorbed boron: A FTIR spectroscopic study. Environmental Science and Technology. 29, 302-311.

Subbiah, B., and Asija, G.L. 1956. A rapid procedure for the estimation of available $\mathrm{N}$ in soils. Current Sciences.
25, 259-260.

Tsadilas, C. D., Yassoglou, C. S., Cosmas, C. S., and Kallianou, C. H. 1994. The availability of soil boron fractions to olive trees and barley and their relationships to soil properties. Plant and Soil. 162, 211-217.

Tsadilas, C.D., and T. Kassioti. 2005. Influence of liming and nitrogen forms on boron uptake by tobacco. Commun. Soil Sci. Plant Anal. 36: 701-708.

Walkley, A. J., and Black, I. A. 1934. An examination of the Degtjareff method for determining soil organic matter and a proposed modification of the chromic acid titration method. Soil Science. 37, 29-38.

Wolf, B. 1971. The determination of boron in soil extracts, plant materials, composts, manures, water, and nutrient solutions. Communication in Soil Science and Plant Analysis. 2, 363-374.

Xu, J. M., Wang, K., Bell, R. W., Yang, Y. A., and Huang, L. B. 2001. Soil Boron Fractions and Their Relationship to Soil Properties. Soil Science Society America Journal. 65, 133-138.

Zarcinas, B. A., and Cartwright, B. 1987. Acid dissolution of soils and rocks for the determination of boron by inductively coupled plasma atomic emission spectrometry. Analyst. 112, 1107-1112.

\section{How to cite this article:}

Prashanta Barman, Arup Sen, Amit Phonglosa and Kallol Bhattacharyya. 2017. Depth Wise Distribution of Boron in Some Soils of Red and Laterite Zone of West Bengal, India. Int.J.Curr.Microbiol.App.Sci. 6(12): 4126-4137. doi: https://doi.org/10.20546/ijcmas.2017.612.474 